\title{
Media społecznościowe a edukacja medialna Nowe rynki pracy
}

\begin{abstract}
Social media and media education. New job markets

Presenting the definition of media education with all its aspects seems to be a breakneck task. Media education is mostly analyzed in relation to a specific phenomenon or process. Digital media, in particular social media, become an important space for media education. Communication platforms of this type are constantly changing and improving. They create a new kind of instability of knowledge and skills. The aim of this work is to present the perspective of social media as new labor markets in the space of the digital information and skills economy.

The analysis in the theoretical layer was based on the work and perspective of Jan van Dijk - social aspects of new media. The secondary analysis of source data and the secondary analysis of in-depth interviews supplemented with author's interviews were used in this work.
\end{abstract}

Key words: social media, media education, economy, social media manager, network society

\section{Wprowadzenie}

Zadaniem karkołomnym wydaje się przedstawienie definicji edukacji medialnej, która prezentowałaby wszystkie jej aspekty. Najczęściej edukację medialną analizuje się w odniesieniu do określonego zjawiska lub procesu. Istotną przestrzenią dla tej dyscypliny stają się media cyfrowe, a w szczególności media społecznościowe. 
Platformy komunikacji tego typu ulegają ciągłym zmianom i ulepszeniom. Tworzą nowy rodzaj niestabilnej wiedzy i nietrwałych umiejętności wymagających ciągłej aktualizacji.

W dobie nowej komunikacji i zmieniającego się krajobrazu medialnego szczególną rolę pełnią platformy, takie jak: Facebook, YouTube, Twitter, Instagram czy Pinterest. W związku z tym każdy użytkownik sieci może stać się członkiem mediów społecznościowych, od dzieci przez młodzież, aż do osób dorosłych.

Celem tej pracy jest przedstawienie perspektywy mediów społecznościowych jako nowych rynków pracy w przestrzeni cyfrowej gospodarki informacji i umiejętności. Analiza w warstwie teoretycznej została oparta na pracy i perspektywie Jana van Dijk'a - Społeczne aspekty nowych mediów, w ramach pracy wykorzystana została wtórna analiza danych źródłowych oraz wtórna analiza wywiadów pogłębionych uzupełniona o wywiady autorskie.

\section{Media społecznościowe i sieci - społeczeństwo sieci}

Internet jako platforma jest jednym z najbardziej popularnych kanałów komunikacji i wymiany informacji. Zgodnie z badaniami przeprowadzonymi przez Gemius PBI (Polskie Badania Internetu) ${ }^{1}$ w grudniu 2017 r. liczba internautów w Polsce wyniosła 27,6 mln, z czego na urządzeniach mobilnych z Internetu korzystało 21,7 mln użytkowników ${ }^{2}$. W ramach badania skomponowana została statystyka najpopularniejszych właścicieli witryn i programów internetowych, z których korzysta najwięcej internautów. Badania te prezentują istotność mediów społecznościowych w ogólnej przestrzeni cyfrowej. Na pierwszym miejscu (ze wskaźnikiem 96,25\%) zasięgu wśród internautów (26 527980 odsłon) plasuje się grupa Google - jako najpopularniejsza witryna/narzędzie w ramach badania. Na drugim miejscu (ze wskaźnikiem 82,22\% zasięgu) wśród internautów (22 659407 odsłon) pojawił się portal Facebook, który w porównaniu do poprzedniego miesiąca (listopad 2017 r.) odnotował przyrost w liczbie odsłon (wskaźnik większy o 209077 względem ubiegłego miesiąca). $\mathrm{Na}$ trzecim miejscu odnotowana została platforma YouTube ze wskaźnikiem na poziomie 77,10\% (21 247989 odsłon). Warto zauważyć, że ten portal w grudniu $2017 \mathrm{r}$. zarejestrował bardzo wysoki wzrost zainteresowania ze strony internautów (711 770

${ }^{1}$ Inicjatywa rozwijana od 1999 r. początkowo pod nazwą Global eMarketing. Zmiana nazwy nastąpiła w 2002 r. Badania publikowane w ramach platformy odnoszą się do rzeczywistej liczby użytkowników (ang. real users) odwiedzających określone strony internetowe. Źródło: https://www.gemius.pl/o-nas.html.

2 Gemius PBI, Wyniki badań Gemius/PBI za grudzień 2017, https://www.gemius.pl/wszystkie-artykuly-aktualnosci/wyniki-badania-gemiuspbi-za-grudzien-2017.html [dostęp: 10.01.2018]. 
więcej odsłon niż w listopadzie 2017 r.). Jedyną witryną, która osiągnęła większy przyrost w ramach tego wskaźnika była platforma cda.pl.

W ramach omawianego badania zebrane zostały także informacje na temat dwudziestu najbardziej popularnych aplikacji internetowych. Na pierwszym miejscu znajdujemy informacje odnoszące się do narzędzia Google, na drugim miejscu pojawiła się aplikacja YouTube, na trzecim miejscu aplikacja Messanger (przynależna do portalu Facebook), sama aplikacja Facebook znalazła się na piątym miejscu w zestawieniu stworzonym na podstawie danych zebranych w grudniu $2017 \mathrm{r}$. Warto wymienić, że w spisie dwudziestu najbardziej popularnych aplikacji internetowych znalazły się także: WhatsApp, Instagram, Hangouts i Snapchat (zasięg wśród internautów 6,72\% i dziewiętnaste miejsce na liście przedstawionej przez Gemius/PBI) ${ }^{3}$. Omawiane wyniki z pewnością pokazują, jak bardzo popularne są media społecznościowe i aplikacje z nimi związane. Intensyfikacja kreowania treści w ramach tych przestrzeni, a także rosnąca liczba użytkowników są siłą napędową mediów społecznościowych. Pojawiają się nowe formaty komunikatów, narzędzia czy aplikacje, które wymagają opanowania i poznania w celu wykorzystania ich pełnego potencjału.

Sieci i społeczności tworzą swoistego rodzaju układ nerwowy społeczeństwa. W takim rozumieniu media społecznościowe pełnią rolę najbardziej istotnych naczyń krwionośnych. Sieciowy format społeczeństwa kładzie nacisk na sposób przetwarzania i wymiany informacji, a także na organizację tej procedury ${ }^{4}$. Społeczeństwo sieci jest zespołem z wewnętrzną infrastrukturą sieci społecznych i przede wszystkim medialnych, które to definiują sposób organizacji i podział na wszystkich poziomach komunikacji - od jednostki do społeczeństwa. Dla komunikacji zachodzącej na poziomie mediów społecznościowych najważniejsza jest jednostka-użytkownik, który jest jednocześnie twórcą treści i komunikatów. Poszczególne platformy są jedynie przestrzenią umożliwiającą komunikację i tworzenie sieci kontaktów. Podstawą wymiany informacji, komunikacji i tworzenia sieci jest słowo - mówione czy też zapisane w dowolnej formie ${ }^{5}$. Kolejne coraz bardziej skomplikowane konstrukcje sieci nie mają służyć jedynie wymianie informacji, ale także wymianie towarów, technologii, idei czy pojęć abstrakcyjnych i systemów wartości.

Czy można zbudować jednoznaczną i spójną definicję sieci? Może być ona rozumiana jako zbiór połączeń między elementami jakiejś jednostki (w zależności od rodzaju sieci definicja ta będzie ulegać uzupełnieniom). Każda sieć składa się minimalnie z trzech połączeń i dwóch elementów (węzłów). Przykładowo sieci społeczne

3 Tamże.

${ }^{4}$ J. van Dijk, Społeczne aspekty nowych mediów, Warszawa 2010, s. 36.

${ }^{5}$ J. McNeill, W. McNeill, The human Web. A Bird'e-eye view of world history, Nowy Jork 2003, s. 4. 
są systemami złożonymi z realnych więzów opartych na abstrakcyjnych relacjach. Natomiast sieci medialne łączą nadawców i odbiorców poprzez transmisję informacji i symboli'. Na styku sieci społecznych i medialnych pojawiają się media społecznościowe łączące nadawców i odbiorców poprzez abstrakcyjne relacje bazujące na realnych więzach (pokrewieństwa, znajomości, zainteresowań i celów). Elementarnym poziomem każdej sieci są relacje między jednostkami, a nie same jednostki. W ujęciu społeczeństwa sieciowego największe znaczenie bowiem mają interakcje, jakie zachodzą między użytkownikami sieci, a nie jednostki same w sobie ${ }^{7}$. System ten staje się podstawą dla mediów społecznościowych, gdzie pierwszym typem relacji są kontakty nawiązane poza mediami społecznościowymi (rodzina, przyjaciele i znajomi). Najbardziej złożonym poziomem komunikacji w ramach sieci są relacje globalne, które operują w przestrzeni światowych systemów społecznych i organizacji międzynarodowych ${ }^{8}$. Współczesne sieci medialne i medialno-społeczne nabierają cech sieci globalnych. Sama wspólnota staje się tworem wirtualnym i wewnętrznie zróżnicowanym, a struktura organizacji sieci opiera się na systemie infokracji zróżnicowanej horyzontalnie. Komunikacja na wielu poziomach jest zapośredniczona przez media interaktywne. Natomiast rosnąca liczba mediów i aplikacji zmusza użytkowników do zdobywania nowych kompetencji i specjalizacji. Sieci i społeczeństwa sieciowe oparte na relacjach zmniejszają znaczenie jednostki na rzecz relacji wyartykułowanych ${ }^{9}$, które wpływają na społeczeństwo i aspekty związane z polityką, kulturą, gospodarką czy życiem codziennym. W ramach omawianych relacji można wydzielić poszczególny grupy, takie jak: relacje materialne, bezpośrednie, on-line i off-line, relacje medialne, interaktywne i wysoce zorganizowane, a także zaszyfrowane i selektywne (wpisujące się w grupę relacji ekskluzywnych). Dla przestrzeni i platform mediów społecznościowych najbardziej istotne są relacje on-line, relacje medialne i interaktywne, a także relacje bezpośrednie (będące bardzo często podstawą budowania relacji typu on-line).

Podstawą mediów społecznościowych są internauci skupieni w ramach komunikacji opartej na zainteresowaniach, celach czy relacjach medialnych i pokrewnych (on-line/off-line czy relacjach bezpośrednich). W ramach szeroko rozumianej platformy komunikacji internauci tworzą sieci wymiany znaczeń i informacji, gdzie poszczególny użytkownik może być członkiem wielu sieci i tworzyć relacje odpowiednie dla poszczególnych konstrukcji. W tej przestrzeni tworzy się nowy typ gospodarki i rynku pracy - model sieciowy.

${ }^{6}$ J. van Dijk, Społeczne aspekty..., dz. cyt., s. 43.

7 J. Brass, A social network perspective on human resources management, „Research in Personnel and Human Resources Management" 1995, nr 13, s. 39-79.

8 J. Urry, Global Complexity, Cambridge 2003, s. 54.

9 J. van Dijk, Społeczne aspekty..., dz. cyt., s. 59-60. 


\section{Nowa gospodarka i nowe miejsca pracy}

Nowe rynki pracy, które powstają w wyniku rozwoju technologicznego i rosnącej specjalizacji komunikacji i sektora usług, związane są przede wszystkim z gospodarczym aspektem rozwoju społeczeństwa. Podobnie jak w przypadku teorii komunikacji cyfrowej możemy tutaj mówić o sieci i gospodarce sieciowej, która jest zdecentralizowana i dynamiczna. Coraz mniejsze znaczenie mają ograniczenia czasowe, przestrzenne czy fizyczne, a istotna staje się aktywność on-line. Podstawą nowej gospodarki, a także funkcją znaczącej liczby nowych (sieciowych) miejsc pracy jest tworzenie przepływu informacji i komunikacji (tworzenie sieci wiedzy). Przepływ ten zamknięty w sieciach wiedzy opiera się na użytkownikach, którzy korzystają z różnego rodzaju platform (w tym także z mediów społecznościowych) w celu wymiany i praktycznego stosowania wiedzy rozumianej jako zbiór informacji i relacji przyczynowo-skutkowych. Bardzo istotną cechą charakterystyczną dla tego rodzaju wiedzy jest migracyjność ${ }^{10}$. Termin ten odnosi się do wszelkich informacji i danych zapisanych w książkach, zestawieniach, raportach, programach i aplikacjach czy bazach danych w skodyfikowanej formie i określonym przeznaczeniu.

Czym zatem charakteryzuje się nowa gospodarka oparta na wiedzy, informacji i komunikacji? Przede wszystkim wysokimi kosztami tworzenia i niskimi kosztami reprodukcji ${ }^{11}$. Proces wytwarzania programów, aplikacji czy baz danych jest czasochłonny i wymaga dużego nakładu pracy - natomiast wtórne wykorzystanie tych narzędzi jest zazwyczaj sekwencją uproszczoną i coraz bardziej intuicyjną dzięki interfejsom, których zadaniem jest wtopić się w środowisko cyfrowości przyjazne dla użytkownika. Nowa gospodarka opiera się na wartościach produktów informacyjnych, dóbr doświadczalnych i centralnym charakterze sieci ${ }^{12}$. Wprowadza zmiany w podstawowej strukturze wymiany dóbr i informacji, ponieważ powoduje odwrócenie łańcucha wartości, czyli konstrukcji obejmującej procesy od produkcji przez dystrybucję do marketingu i konsumpcji. Popyt staje się ważniejszy niż podaż - odwrócona zostaje tradycyjna formuła gospodarki i jej wartości ${ }^{13}$. To użytkownicy określają swoje zapotrzebowania w zakresie dóbr i usług czy nawet tekstów kultury (sieci fanów mają bezpośredni wpływ na losy seriali lub obsady wielkich produkcji filmowych - ich zdanie jest brane pod uwagę przez

${ }^{10} \mathrm{~J}$. Badaracco, The knowledge Link. How firms copete through strategies in a changing world, Londyn 1991, s. 44.

11 J. van Dijk, Społeczne aspekty..., dz. cyt., s. 113-115.

${ }^{12}$ C. Shapiro, R. Varian, Potega informacji. Strategiczny przewodnik po gospodarce sieciowej, Gliwice 2007, s. 14.

${ }_{13}$ J. Rayport, J. Sviokla, Exploiting the virtual value chain, [w:] Creating value in the network economy, red. D. Tapscott, Boston 1999, s. 109-112. 
producentów i dystrybutorów). Tym samym w wyniku tego procesu następuje podział i dematerializacja łańcucha wartości ${ }^{14}$. Poszczególne podmioty specjalizują się w pojedynczym etapie produkcji lub dystrybucji (przykład e-handlu). Rodzajem działania tego typu może być także zarządzanie i operowanie siecią (społecznościową/medialną). W tej przestrzeni także powstają nowe rynki pracy i zawody, takie jak content designer czy social media manager (charakterystyka tych zawodów zostanie omówiona $\mathrm{w}$ dalszej części pracy). Istotne staje się budowanie komunikacji w ramach sieci i społeczne projektowanie produktu oraz jego adaptacja w kontekście konsumpcji.

\section{Edukacja medialna w przestrzeni mediów społecznościowych}

Jakie znaczenie ma edukacja medialna w ramach platform komunikacji, jakimi są media społecznościowe? Czy nauczanie zinstytucjonalizowane może być skuteczne w obliczu tak dynamicznego i hybrydowego środowiska, jakim jest Internet i omawiane media czy portale? Jednym z podstawowych zadań edukacji medialnej w takim kontekście jest planowanie przekazu i podmiotowe podejście do studenta zapewniające przestrzeń zachęcającą do twórczości i rozwoju własnego ${ }^{15}$. Sam proces edukacji oparty na zdobywaniu wiedzy w wypadku przestrzeni mediów społecznościowych powinien opierać się na działaniu w określonym środowisku i tworzeniu scenariuszy możliwych sytuacji i ich efektów, a także reakcji, jakie za sobą pociągają (prognozowanie i przewidywanie konsekwencji działań i publikacji). Nie jest problemem techniczne opanowanie narzędzi przynależnych do określonych portali. Problemem jest skonstruowanie komunikatu, który w określonej przestrzeni odniesie sukces i nie będzie wypadkową zbiegów okoliczności, a precyzyjnym działaniem. Kolejnym elementem układanki, jaką stanowią media społecznościowe, jest powtarzalność, czyli umiejętność prowadzenia udanej narracji w przestrzeni komunikatów i narzędzi.

Równie istotnym zadaniem edukacji medialnej jest wprowadzanie i kształtowanie umiejętności krytycznego odbioru treści medialnych ${ }^{16}$. Odpowiednia wiedza teoretyczna i narzędzia odbioru tego typu treści umożliwiają krytyczne spojrzenie na kwestie związane ze stroną merytoryczną czy estetyczną przekazu. W większości przypadków jednak wiedza i doświadczenie w tej kwestii są zdobywane

14 Tamże.

15 A. Krzeszewska, Twórczość a rozwój świadomości człowieka, „Innowacje w edukacji akademickiej" 2002, nr 1, s. 21-28.

16 M. Bolińska, Prymat obrazka, czyli rola mediów audiowizualnych $w$ upowszechnianiu kultury, [w:] Kultura popularna w szkole. Pobłażliwe przyzwolenie czy autentyczny dialog?, red. B. Myrdzik, M. Latoch-Zielińska, Lublin 2006, s. 158-161. 
głównie w ramach praktyki zawodowej, co zdecydowanie spowalnia proces specjalizacji rynkowej i przekazu samego w sobie. Oczywiście należy zaznaczyć, że edukacja jest procesem ciągłym i w dużej mierze zindywidualizowanym. Ma charakter jednostkowy, jednak edukacja medialna $\mathrm{w}$ formie zinstytucjonalizowanej powinna nauczać języka mediów, kodów odbioru, a przede wszystkim krytycznego analizowania treści medialnych ${ }^{17} \mathrm{w}$ zmieniającym się i ewoluującym środowisku mediów społecznościowych. Nie ulega wątpliwości, że takie cele są podejmowane w ramach prowadzonych kursów, przedmiotów uniwersyteckich i szkoleń (zinstytucjonalizowana edukacja medialna). Pytanie, jakie się nasuwa, odnosi się jedynie to intensywności, liczebności i zasadniczości (poruszyć tu należy kwestie związane $\mathrm{z}$ analizowanym materiałem czy znaczeniem problematyki omawianej $\mathrm{w}$ ramach kształcenia akademickiego) tego typu inicjatyw.

Internet i media społecznościowe pełnią określone funkcje społeczne i technologiczne w ramach komunikacji społeczności. Biorąc pod uwagę ten stan rzeczy, umiejętność krytycznego odbioru komunikatów medialnych jest szczególnie istotna. Znaczna część użytkowników sieci i odbiorców komunikatów medialnych może być określona mianem cyfrowych tubylców. Głównym trzonem tej grupy są młodzi ludzie intensywnie korzystający z nowych mediów do kreowania i podtrzymywania kontaktu $z$ otoczeniem społecznym ${ }^{18}$. Kompetencje komunikacyjne związane z komunikowaniem się on-line cyfrowi tubylcy zdobywają poprzez działanie i partycypację w ramach grup społecznych i platform komunikacji ${ }^{19}$. Generacja ta ma się cechować szczególną ekspresją, inwencją twórczą czy chęcią rozwoju $\mathrm{w}$ kierunku kompetencji medialnych i cyfrowych ${ }^{20}$. Są to osoby samodzielne i dociekliwe, a przede wszystkim bardzo świadome procesów zachodzących w społeczeństwie i społecznościach. Ich umiejętności są niesamowitą wartością, jednak przy braku odpowiedniego wsparcia i wiedzy opartej na dogłębnej analizie nie są w stanie kreować stabilnej narracji i skutecznie poruszać się w ramach nowej gospodarki cyfrowej.

Nawet media społecznościowe, które mogłyby się wydawać habitusem cyfrowych tubylców, przechodzą ciągłe przemiany związane z profesjonalizacją i modyfikacją. Zestawy umiejętności i schematy myślenia użytkowników w związ$\mathrm{ku} \mathrm{z}$ tym procesem muszą ulegać ciągłym uaktualnieniom na podobieństwo

${ }_{17}$ M. Bolińska, Prymat obrazka..., dz. cyt., s. 150-151.

${ }_{18} \mathrm{H}$. Tomaszewska, Młodzież, rówieśnicy i nowe media. Społeczne funkcje technologii komunikacyjnych $w$ życiu nastolatków, Warszawa 2012, s. 125.

19 D. Suess, Media use and the relationships of children and teenagers with their peer groups, „European Journal of Communications" 1998, nr 4, s. 522.

${ }_{20}$ D. Buckingham, Is there a digital generation?, [w:] Digital generations. Children, young people and new media, red. D. Buckinghan, R. Willett, Nowy Jork 2006, s. 6-10. 
aktualizacji oprogramowania typu software. Edukacja medialna w otoczeniu mediów społecznościowych powinna kształtować społecznie budowaną bazę danych opartą na krytycznym odbiorze treści i otwartym modelu odbierania przekazów medialnych. Ma to na celu celu przygotowanie odbiorców czy użytkowników do rzeczywistości płynnych znaczeń i nieustających zmian, jakie zachodzą w omawianej przestrzeni komunikacji.

\section{Content designer czy social media manager?}

Przestrzeń mediów społecznościowych i branża usług interaktywnych opiera swe działania na wiedzy z zakresu marketingu, psychologii społecznej i analitycznej. Prowadzenie mediów społecznościowych w ramach stanowiska określanego jako social media manager (SMM) lub social media specialist czy nawet social media animator wymaga otwartego i analitycznego sposobu myślenia, innowacyjności i kreatywności. Obecnie bardzo trudno znaleźć studia specjalizujące się w edukacji medialnej związanej bezpośrednio z mediami społecznościowymi ${ }^{21}$, jednak nie brakuje studiów na temat marketingu, komunikacji społecznej czy socjologii. Studia takie także kształtują i pielęgnują istotne dla mediów cyfrowych umiejętności i miękkie narzędzia komunikacji czy zarządzania (w tym popularne narzędzia HR).

Rozpoczynając pracę jako social media manager, można przejść żmudną drogę zbierania doświadczenia w celu uzyskania specjalizacji odpowiedniej dla stanowiska określanego jako content designer (CD), czyli kreator treści (odpowiednio zgodnie z reżimem firmy kreator treści może uzyskać stopień juniora, właściwego $\mathrm{CD}$ i seniora). Praca związana $\mathrm{z}$ tym stanowiskiem nie zamyka się jedynie w aspekcie związanym z kreowaniem treści, ale opiera się na planowaniu i tworzeniu harmonogramów i strategii publikacji. Twórca treści zgodnie z wypowiedzią Michała Zgudka udzieloną na potrzeby wywiadu dla portalu nowymarketing.pl (Content Designer SMD) prowadzi także stałą współpracę z działami klienckimi oraz samym klientem ${ }^{22}$. Idealny twórca treści powinien bardzo precyzyjnie posługiwać się słowem i gatunkami publicystycznymi, powinien posiadać umiejętności związane z obróbką graficzną i podstawowymi interfejsami systemowymi (social media i pakiety biurowe). Jedną z istotnych umiejętności dla tego zawodu jest także zdolność tworzenia i sprzedawania (pitching) prezentacji multimedialnych.

${ }^{21}$ studia.net, Zawód: Specjalista ds. social media, http://www.studia.net/zawody/7458-specjalista-ds-social-media [dostęp: 15.01.2018].

${ }^{22}$ nowymarketing.pl, Zawód: specjaliści od social media (kariera w marketingu) (cz. 2), https:// nowymarketing.pl/a/8425,zawod-specjalisci-od-social-media-kariera-w-marketingu-cz-2 [dostęp: 15.01.2018]. 
Kolejnym aspektem ważnym dla nowej gospodarki informacji i dla nowych miejsc pracy, takich jak SMM są narzędzia analityczne, umiejętności związane ze strategicznym budowaniem komunikacji, brandingiem i klasycznym marketingiem. Szczególnie planowanie i analityka komunikacji i skuteczności działań prowadzonych w ramach mediów społecznościowych nabiera ogromnego znaczenia - pozwala na przewidywanie trendów i ocenianie obecnie istniejących tendencji w celu lepszego programowania zadań i celów na przyszłość. Social media manager musi być osobą wszechstronną ${ }^{23}$ zgodnie z opinią Michała Sławińskiego Social Media Innovation Director agencji K2. Najbardziej istotnym aspektem tego typu pracy jest wiedza, która ulega ciągłej dezaktualizacji, co kreuje potrzebę zdobywania informacji i tworzenia schematów komunikacji.

Edukacja medialna tak istotna dla środowiska omawianych zawodów skupia się także w ramach licznych inicjatyw i szkoleń, takich jak spotkania cykliczne Geek Girls Carrots w Lublinie. Jedną z twórczyń tej inicjatywy jest Jagoda Greczycho, która opisuje to wydarzenie jako promowanie kobiet w branży IT $^{24}$. Spotkania skupiają się na networkingu i samorozwoju. Mają zachęcać do podejmowania wyzwań w branżach związanych z nowymi technologiami. Głównym celem tych spotkań (18 spotkań zrealizowanych pod nazwą Geek Girls Carrots) jest wymiana doświadczeń, prezentacja najnowszych rozwiązań informatycznych oraz integracja środowiska i sieci ${ }^{25}$.

\section{Wnioski}

Media społecznościowe mają ogromną moc sprawczą. Dla grupy cyfrowych tubylców przedstawiają one rzeczywistość i pozwalają na partycypację w komunikacji masowej, a także są źródłem informacji niedostępnej w inny sposób. Media społecznościowe wpisujące się $\mathrm{w}$ grupę mediów cyfrowych nieustannie zmieniają krajobraz gospodarki i przemysłu informacji, tworząc nowe perspektywy, miejsca pracy i doprecyzowane profile zawodowe. Media w swoim środowisku kreują perspektywy, jednak bez odpowiedniego przygotowania merytorycznego i wiedzy z zakresu teorii mediów mogą w odbiorze tłumić stabilny przepływ informacji. Bez ukształtowanego spojrzenia krytycznego tworzą u odbiorcy efekt szumu informacyjnego, który uniemożliwia efektywne korzystanie z podanych źródeł i platform komunikacji.

\footnotetext{
23 Tamże.

24 Materiały własne - wywiad.

${ }^{25}$ Na podstawie wywiadu przeprowadzonego z Jagodą Greczycho dnia 24.01.2018 r.
} 
Media społecznościowe są płynną materią złożoną z użytkowników, kreowanej treści i jej odbioru, a w dalszym aspekcie interpretacji. To techniki i schematy komunikacji społecznej zamknięte $\mathrm{w}$ narzędziach cyfrowych przynależnych do określonych platform komunikacji (Facebook, YouTube, Twitter czy Pinterest lub Instagram). Rozwój tych form komunikacji doprowadził do profesjonalizacji tych kanałów i komunikatów udostępnianych za ich pomocą, co pociągnęło za sobą zapotrzebowanie na specjalistów we wspomnianym zakresie. Tak wykrystalizowały się zawody określane jako social media manager czy content designer (twórca treści).

Rozwój nowych technologii jest motorem postępu społecznego w ogóle, a w szczególności odnosi się do gospodarki i komunikacji rozumianej jako wymiana informacji i umiejętności. Prędkość zmian społecznych prowokowanych przez media zmusza jednostkę-użytkownika do ciągłego rozwoju i krytycznej analizy trendów i zachowań. W tym aspekcie istotna staje się misja edukacji medialnej, która ma przygotować uczestnika komunikacji medialnej na płynność rzeczywistości i proces natychmiastowej dezaktualizacji wiedzy w przestrzeniach takich jak media społecznościowe.

To, jakie są media, w dużym stopniu zależy od tego, jak rozwija się współczesne społeczeństwo, w tym jak nowe technologie są w stanie zmienić jego styl życia i zachowania. Zmiana społeczeństwa pociąga za sobą zmiany gospodarcze, które $\mathrm{w}$ kolejności zmieniają rynek pracy i przestrzeń zawodową bezpośrednio związaną z mediami cyfrowymi, a w tym społecznościowymi.

\section{BIBLIOGRAFIA}

Badaracco J., The knowledge Link. How firms copete through strategies in a changing world, Londyn 1991.

Bolińska M., Prymat obrazka, czyli rola mediów audiowizualnych w upowszechnianiu kultury, [w:] Kultura popularna w szkole. Pobłażliwe przyzwolenie czy autentyczny dialog?, red. B. Myrdzik, M. Latoch-Zielińska, Lublin 2006.

Brass J., A social network perspective on human resources management, „Research in Personnel and Human Resources Management" 1995, nr 13.

Buckingham D., Is there a digital generation?, [w:] Digital generations. Children, young people and new media, red. D. Buckinghan, R. Willett, Nowy Jork 2006.

Gemius PBI, Wyniki badań Gemius/PBI za grudzień 2017, https://www.gemius. $\mathrm{pl}$ /wszystkie-artykuly-aktualnosci/wyniki-badania-gemiuspbi-za-grudzien-2017.html [dostęp: 10.01.2018]. 
Krzeszewska A., Twórczość a rozwój świadomości człowieka, „Innowacje w Edukacji Akademickiej" 2002, nr 1.

McNeill J., McNeill W., The human Web. A Bird'e-eye view of world history, Nowy Jork 2003.

Nowymarketing.pl, Zawód: specjaliści od social media (kariera w marketingu) (cz. 2), https://nowymarketing.pl/a/8425,zawod-specjalisci-od-social-media-kariera-w-marketingu-cz-2 [dostęp: 15.01.2018].

Rayport J., Sviokla J., Exploiting the virtual value chain, [w:] Creating value in the network economy, red. Don Tapscott, Boston 1999.

Shapiro C., Varian R., Potega informacji. Strategiczny przewodnik po gospodarce sieciowej, Gliwice 2007.

Studia.net, Zawód: Specjalista ds. social media, http://www.studia.net/zawody/ 7458-specjalista-ds-social-media [dostęp: 15.01.2018].

Suess D., Media use and the relationships of children and teenagers with their peer groups, „European Journal of Communications” 1998, nr 4.

Tomaszewska H., Młodzież, rówieśnicy i nowe media. Społeczne funkcje technologii komunikacyjnych w życiu nastolatków, Warszawa 2012.

Urry J., Global Complexity, Cambridge 2003.

Van Dijk J., Społeczne aspekty nowych mediów, Warszawa 2010. 